\title{
Standardization and Evaluation of Probiotic Shrikhand
}

\author{
R. Sivasankari ${ }^{1 *}$, G. Hemalatha ${ }^{1}$, S. Kanchana ${ }^{2}$ and T. Umamaheswari ${ }^{1}$ \\ ${ }^{1}$ Department of Food Science and Nutrition, Home Science College and Research Institute, \\ Madurai - 625 104, Tamil Nadu, India \\ ${ }^{2}$ Department of Post-Harvest Technology Centre, Tamil Nadu Agricultural University, \\ Coimbatore - 641 003, Tamil Nadu, India \\ *Corresponding author
}

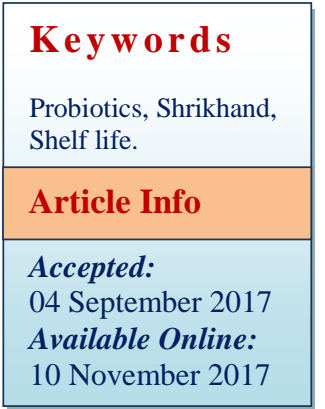

A B S T R A C T

In India, among the different indigenous fermented milk products 'Shrikhand' assumes special importance for its sensory attributes. The present investigation was envisioned to standardize and evaluate probiotic shrikhand using single (Lactobacillus acidophilus) and mixed probiotic strains (Lactobacillus acidophilus and Lactobacillus rhamnosus). The chemical constituents such as moisture, total solid content, protein, fat, ash, $\mathrm{pH}$, acidity, reducing and total sugars of the probiotic shrikhand were analyzed. The viable probiotic count of shrikhand was recorded as $25 \times 10^{12} \mathrm{cfu} \mathrm{g}^{-1}$ for L. acidophilus and $30 \times 10^{12} \mathrm{cfu} \mathrm{g}^{-1}$ for mixed probiotic strains in fresh shrikhand. During storage, the viability of probiotics was decreased due to increase in acidity i.e. L. acidophilus and mixed probiotic stains had the viable probiotic count of $20 \times 10^{12} \mathrm{cfu} \mathrm{g}^{-1}$. The moisture and $\mathrm{pH}$ were noticed to decrease during storage whereas acidity and total solid content were increased on storage. Storage study of probiotic shrikhand had good storage stability during 30 days of storage at refrigeration temperature $\left(4^{\circ} \mathrm{C}\right)$. Probiotic shrikhand could thus serve as good carrier of probiotics to improve gut health and also suitable for lactose intolerant individuals.

\section{Introduction}

Probiotics are viable microbial dietary supplements that, when introduced in sufficient quantities, positively influence the health mainly by improving the composition of intestinal microbiota. The World Health Organization (2001) defined probiotics as "live microorganisms which, when administered in adequate amounts, confer a health benefit on the host". Probiotics can survive better in dairy products than in nondairy foods. Most of the probiotics can readily utilize lactose as an energy source for growth. Milk is one of the most important natural products consumed by people all around the world in one form or another. During fermentation the microorganisms convert lactose into lactic acid and its metabolites which confers improved digestibility and nutrition.

The technology of application of probiotic organisms in fermented dairy products in general, aims to combine the nutritional value of milk and the health benefits of the bacteria with their ability to grow in milk, resulting in a nutritionally healthy and desirable product for the consumers. For the commercial production of probiotic enriched fermented 
milk products, it is important to select suitable dairy starter cultures. These starter cultures are carefully selected microorganisms, which are deliberately added to milk to initiate and carry out desired fermentation under controlled conditions in the production of fermented milk products. Most of them belong to lactic acid bacteria (Lactococcus, Lactobacillus, Streptococcus and Leuconostoc). Starter cultures can be used as single strain, mixed strain and as multiple strains depending upon the type of products to be prepared. The probiotic strain in use should be resistant to stomach acidity, pancreatic and bile secretion.

Fermented milk products are generally sour milk products prepared by fermenting milk by means of specific dairy starter cultures. The important fermented milks in India are dahi, shrikhand, lassi, butter milk, yoghurt etc., It is estimated that approximately eight per cent of milk produced in the country is converted into fermented milk (Aneja et al., 2002). Consumption of fermented milk provides lot of health benefits beyond basic nutrition. Fermented milk has become increasingly popular in recent times on account of being important sources of probiotics in our diet. Shrikhand is one of the fermented milk delicacies and is derived from the Sanskrit word "Shrikharini", meaning a curd preparation with added sugar, flavouring material, fruits and nuts. Shrikhand is a semisolid, sweetish sour, wholesome and indigenous fermented milk product popular in Maharashtra and Karnataka (Desai and Gupta, 1986). Shrikhand, obtained from curd (dahi), contains most of the valuable constituents of milk such as protein, fat, minerals, fat soluble vitamins and an appreciable amount of Bcomplex vitamins, particularly riboflavin and folic acid. On account of the nutritional importance, the present study was designed to develop the technology for probiotic shrikhand, by optimizing the appropriate starter culture, level of inoculum and incubation period. Under this background, the present study was carried out with the following objectives.

To standardise probiotic shrikhand using selected probiotics.

To evaluate the quality characteristics of the probiotic shrikhand.

To study the shelf life of probiotic shrikhand.

\section{Materials and Methods}

\section{Microbial cultures and other ingredients}

The starter culture Lactobacillus acidophilus (NCDC 14) was obtained from the National Collection of Dairy Cultures (NCDC), National Dairy Research Institute (NDRI), Karnal. The mixed probiotic strains, Lactobacillus acidophilus and Lactobacillus rhamnosus were obtained from Darolac, Mumbai. Milk and other ingredients were purchased from the local market of Madurai.

\section{Preparation of starter culture}

The freeze dried LAB cultures were revived in MRS broth by incubating at $40 \pm 2^{\circ} \mathrm{C}$ for $24-$ $48 \mathrm{~h}$. The revived cultures were re-inoculated in MRS broth and incubated for 12-16 $\mathrm{h}$ at $40 \pm 1^{\circ} \mathrm{C}$. Then $1 \mathrm{ml}$ of the cultures were transferred into $10 \mathrm{ml}$ of sterile 12 per cent Reconstituted Skim Milk (RSM) and incubated for $12-16 \mathrm{~h}$ at $40 \pm 1{ }^{\circ} \mathrm{C}$.

\section{Preparation of yogurt and chakka}

Toned milk (3.0\% fat, $8.5 \%$ SNF) was boiled at $95^{\circ} \mathrm{C}$ for $7 \mathrm{~min}$ and cooled to the temperature of around $40^{\circ} \mathrm{C}$. After cooling, the probiotic cultures, Lactobacillus acidophilus/ Lactobacillus acidophilus + Lactobacillus rhamnosus were added in the 
milk@2 per cent inoculum and incubated at $40^{\circ} \mathrm{C}$ for 15 hours. After incubation, the yogurt was drained in muslin cloth for 13 hours to get chakka in refrigeration temperature.

\section{Preparation of plain shrikhand}

Powdered sugar (40\%) and powdered cardamom $(1.2 \%)$ were added to the chakka and kneaded well by using electric blender.

\section{Storage studies}

The probiotic shrikhand was packed in polystyrene cups and stored under refrigeration condition $\left(4^{\circ} \mathrm{C}\right)$. The packed probiotic enriched shrikhand samples conforming to the different treatments $\left(\mathrm{T}_{\mathrm{s}}\right.$ and $T_{m}$ ) were studied for storage stability during a storage period of 30 days under refrigeration temperature $\left(4^{\circ} \mathrm{C}\right)$. The chemical, microbial and sensory analysis of the stored samples were analysed using standard procedure as mentioned by AOAC at regular intervals of 10 days during the period of storage (30 days).

\section{Viability of probiotic bacteria in shrikhand}

Viability of probiotic bacteria was determined during the storage by serial dilution method at 10 days intervals. One gram of probiotic shrikhand samples were weighed and serially diluted up to $10^{14}$ dilutions. The probiotic bacterial population was enumerated by pour plate technique using MRS media after incubation at $40^{\circ} \mathrm{C}$ for $48 \mathrm{~h}$. The results were expressed as $\log \mathrm{cfu} \mathrm{ml}^{-1}$.

\section{Microbial quality of shrikhand}

The microbial quality of shrikhand during storage was enumerated by serial dilution method as described by Istavankiss (1984). Yeast and mold count and coliform count for probiotic shrikhand were assessed on 0,10 , 20 and 30 days of storage. Dilution of $10^{-3}$ and $10^{-4}$ was used for yeast and mold count and $10^{-1}$ and $10^{-2}$ was used for coliforms. It was then pour plated using yeast extract malt extract agar and violet red bile agar respectively and then incubates at room temperature for 3-5 days for yeast and mold and 1-2 days for coliforms.

\section{Organoleptic evaluation}

Organoleptic evaluation of the sample was done by 20 semi trained judges at regular intervals of 10 days during 30 days of storage study using nine point hedonic rating scale to grade probiotic shrikhand with the scores ranging from like extremely (9.0) to dislike extremely (1.0) (Amerine et al., 1965).

\section{Statistical Analysis}

The data obtained were subjected to statistical analysis to determine the impact of treatments, storage periods and their interaction on the quality of probiotic shrikhand. Factorial Completely Randomized Design (FCRD) was applied for the statistical analysis (Rangaswamy, 1995).

\section{Results and Discussion}

\section{Chemical constituents}

\section{Moisture and total solid content}

The moisture content for the shrikhand developed from the mixed probiotic strains $\left(\mathrm{T}_{\mathrm{m}}\right)$ was 43.33 per cent compared to 45.12 per cent in single culture L. acidophilus $\left(\mathrm{T}_{\mathrm{s}}\right)$. The decrease in moisture content was observed in both the samples i.e. $\mathrm{T}_{\mathrm{s}}(43.27 \%)$ and $\mathrm{T}_{\mathrm{m}}(41.60 \%)$ during storage. In congruence to the decrease in moisture content as shown in Table 1, there was a corresponding increase in total solid content 
in all the shrikhand samples. The total solid content of the shrikhand samples, carrying the single culture $\left(\mathrm{T}_{\mathrm{s}}\right)$ was 54.88 per cent and mixed probiotic strains enriched shrikhand $\left(\mathrm{T}_{\mathrm{m}}\right)$ was 56.62 per cent. The increase in total solid content during storage may be augmented to the decrease in moisture content on storage.

From the results, it was revealed that mixed culture (L. acidophilus and L. rhamnosus) enriched shrikhand had more total solid content than single culture (L. acidophilus) enriched shrikhand. In probiotic shrikhand, significant difference was noticed for changes in moisture content among the different treatments, period of storage and their interaction (Tables 2 and 3).

\section{Protein and fat}

The protein and fat content for the shrikhand developed from the mixed probiotic strains $\left(\mathrm{T}_{\mathrm{m}}\right)$ were 6.80 and $10.45 \mathrm{~g} / 100 \mathrm{~g}$ respectively whereas in single culture L. acidophilus $\left(\mathrm{T}_{\mathrm{s}}\right)$ it was 6.75 and $6.80 \mathrm{~g} / 100 \mathrm{~g}$ respectively. While analyzing the changes in the protein content of the shrikhand samples conforming to the different treatments during storage a slight increase in protein content was noticed in all the shrikhand samples. A slight reduction in fat content was noticed in all the shrikhand samples (Table 1). Statistical analysis recorded significant difference in terms of protein content among the different treatments and also in terms of storage period.

\section{Ash}

The ash content of shrikhand samples $\left(\mathrm{T}_{\mathrm{s}}\right.$ and $\mathrm{T}_{\mathrm{m}}$ ) were 0.60 per cent. No significant change was noticed in the ash content levels of the shrikhand samples during storage of 30 days. Kumar et al., (2011) reported that the mean ash percentage values of shrikhand ranged from 0.25 to 0.59 per cent. There was no change in ash content during the entire storage period under refrigeration temperature. Nigam et al., (2009) also reported that the storage period did not affect the ash content of the prepared shrikhand. Similar results were obtained from the present study.

\section{pH and acidity}

The $\mathrm{pH}$ and acidity values of probiotic shrikhand samples $\left(\mathrm{T}_{\mathrm{m}}\right)$ were 4.07 and 1.50 per cent whereas compared to 4.00 and 1.44 per cent in $\mathrm{T}_{\mathrm{s}}$ samples. A significant decrease in $\mathrm{pH}$ was noticed during storage in all the samples which may be augmented to the increase in acidity during storage (Table 1). From the results it was concluded that the mixed culture (L. acidophilus and $L$. rhamnosus) had more acidity when compared to single culture (L. acidophilus). Acidity was increased in all experimental samples during storage. Because, during post-acidification period, the activity of probiotic cultures were not completely stopped, which may have produced lactic acid up to the availability of the nutrients present in the yoghurt. Similar results were reported by Manjula et al., (2012).

\section{Reducing sugars and total sugars}

The reducing and total sugar content of the samples was 2.20 and $45.64 \mathrm{~g} / 100 \mathrm{~g}$ respectively in $T_{m}$ whereas in $T_{s}$ the corresponding values were 2.30 and $48.50 \mathrm{~g} /$ $100 \mathrm{~g}$ respectively. From the Table 1 , it can be inferred that there was an increasing trend of reducing sugar in all probiotic shrikhand samples. The increase in reducing sugar levels during storage of the shrikhand samples was attributed to the breakdown of total sugar into simple sugars. During storage, the total sugar was found to be decreased which might be due to the breakdown of carbohydrates (Raghuwanshi et al., 2011). 
Table.1 Changes in chemical constituents during storage of probiotic enriched shrikhand

\begin{tabular}{|l|c|c|c|c|}
\hline \multirow{2}{*}{$\begin{array}{c}\text { Chemical constituents / } \\
\text { Treatments }\end{array}$} & Initial & Final & Initial & Final \\
\cline { 2 - 5 } & 45.12 & 43.27 & 43.33 & 41.70 \\
\hline Moisture (\%) & 54.88 & 56.58 & 56.62 & 58.30 \\
\hline Total solid content (\%) & 6.75 & 7.15 & 6.80 & 7.32 \\
\hline Protein (g) & 10.57 & 10.15 & 10.45 & 10.05 \\
\hline Fat (\%) & 0.60 & 0.60 & 0.60 & 0.60 \\
\hline Ash (\%) & 4.07 & 3.84 & 4.00 & 3.76 \\
\hline pH & 1.44 & 1.68 & 1.50 & 1.75 \\
\hline Acidity (\%) & 2.30 & 2.54 & 2.20 & 2.52 \\
\hline Reducing sugar (g) & 48.50 & 45.45 & 48.05 & 45.64 \\
\hline Total sugar (g) & & &
\end{tabular}

Table.2 Statistical analysis for L. acidophilus enriched shrikhand

\begin{tabular}{|c|c|c|c|}
\hline SOURCE & SED & CD (0.05) & CD (0.01) \\
\hline T & 0.06060 & 0.12081 & $0.16035^{* *}$ \\
\hline S & 0.04040 & 0.08054 & $0.10690^{* *}$ \\
\hline TS & 0.12121 & 0.24162 & $0.32070^{* *}$ \\
\hline
\end{tabular}

Table.3 Statistical analysis for L. acidophilus and L. rhamnosus enriched shrikhand

\begin{tabular}{|c|c|c|c|}
\hline SOURCE & SED & CD (0.05) & CD (0.01) \\
\hline T & 0.04088 & 0.08150 & $0.10817^{* *}$ \\
\hline S & 0.02726 & 0.05433 & $0.07211^{* *}$ \\
\hline TS & 0.08177 & 0.16300 & $0.21634^{* *}$ \\
\hline
\end{tabular}

Table.4 Changes in sensory attributes during storage of probiotic enriched shrikhand

\begin{tabular}{|l|c|c|c|c|}
\hline \multirow{2}{*}{$\begin{array}{c}\text { Sensory attributes / } \\
\text { Treatments }\end{array}$} & \multicolumn{2}{|c|}{ Ts } & \multicolumn{2}{c|}{ Tm } \\
\cline { 2 - 5 } Colour & Initial & Final & Initial & Final \\
\hline Flavour & 9.00 & 8.00 & 9.00 & 8.00 \\
\hline Texture & 9.00 & 8.50 & 9.00 & 8.50 \\
\hline Taste & 9.00 & 8.00 & 8.50 & 7.50 \\
\hline Overall acceptability & 9.00 & 8.50 & 8.50 & 8.00 \\
\hline
\end{tabular}

Table.5 Changes in microbial quality during storage of probiotic enriched shrikhandcfu $\mathrm{g}^{-1}$

\begin{tabular}{|l|c|c|c|c|c|c|c|c|}
\hline \multirow{2}{*}{$\begin{array}{c}\text { Microbial quality / } \\
\text { Treatments }\end{array}$} & \multicolumn{3}{|c|}{ Ts } & \multicolumn{4}{c|}{ Tm } \\
\cline { 2 - 9 } Initial & \multicolumn{2}{|c|}{ Final } & \multicolumn{2}{c|}{ Initial } & \multicolumn{2}{c|}{ Final } \\
\hline \multirow{2}{*}{ Viability } & $10^{12}$ & $10^{13}$ & $10^{12}$ & $10^{13}$ & $10^{12}$ & $10^{13}$ & $10^{12}$ & $10^{13}$ \\
\cline { 2 - 9 } & 25 & 21 & 20 & 17 & 30 & 27 & 20 & 18 \\
\hline \multirow{2}{*}{ Yeast and mould count } & $10^{1}$ & $10^{2}$ & $10^{1}$ & $10^{2}$ & $10^{1}$ & $10^{2}$ & $10^{1}$ & $10^{2}$ \\
\cline { 2 - 8 } & - & - & - & - & - & - & - & - \\
\hline $\begin{array}{l}\mathrm{T}_{\mathrm{s}}-\text { Shrikhand enriched with single culture (L. acidophilus) } \\
\mathrm{T}_{\mathrm{m}}-\text { Shrikhand enriched with mixed culture (L.acidophilus and L. rhamnosus) }\end{array}$ \\
\hline
\end{tabular}


Fig.1 Viability of probiotics during storage

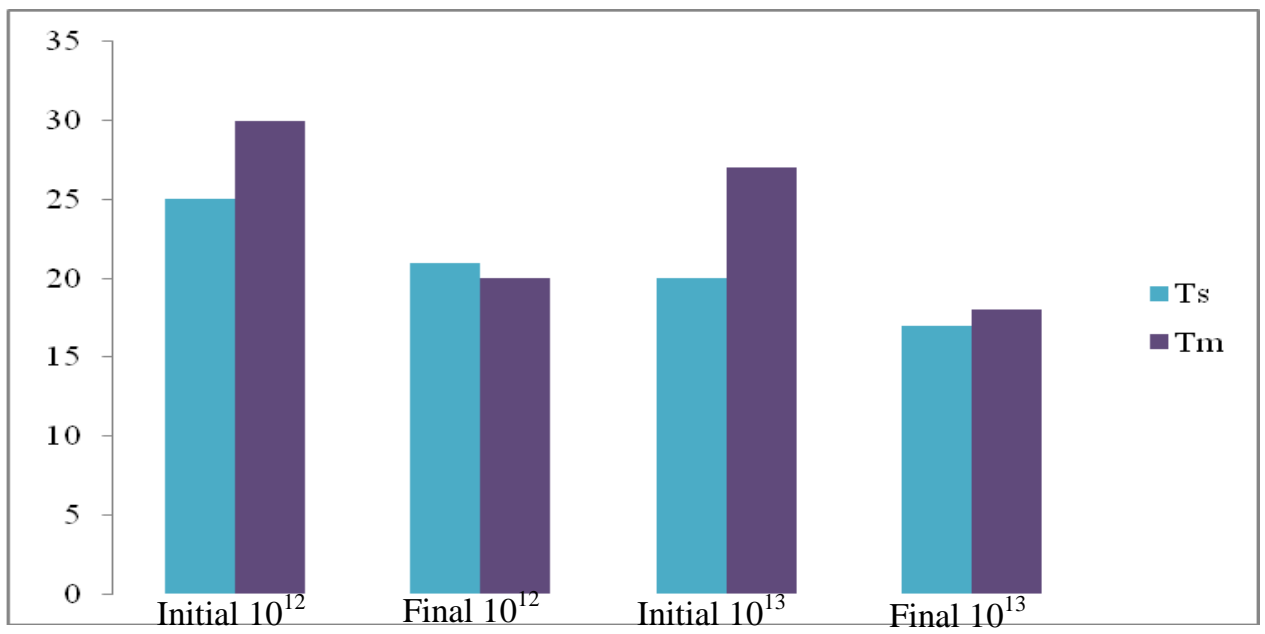

Raghuwanshi et al., (2011) reported that fresh shrikhand contained on an average 2.96 per cent reducing sugar which was increased to 3.68 per cent in 5 days of storage irrespective of the storage temperatures. Significant increase in reducing sugar content was observed with increase in storage period which are in line with the results of the present study.

\section{Sensory attributes}

The sensory attributes such as colour, flavour, texture, taste and overall acceptability was acceptable in both the samples. But the single culture enriched probiotic recorded high sensory score (9.00) when compared to the mixed probiotic strains enriched shrikhand which had less score (8.75). During storage, the acceptability level was slightly decreased and score value was in the range of 8.00 to 8.25 (Table 4) and both the products were found to be acceptable during the entire storage period (30 days).

\section{Microbial quality}

\section{Viability}

The viability count of $L$. acidophilus enriched shrikhand was $25 \times 10^{12} \mathrm{cfu} \mathrm{g}^{-1}$ and $21 \times 10^{13} \mathrm{cfu}$ $\mathrm{g}^{-1}$ whereas in mixed probiotic strains enriched shrikhand, the viability count was $30 \times 10^{12}$ cfu $\mathrm{g}^{-1}$ and $27 \times 10^{13}$ cfu $\mathrm{g}^{-1}$ (Table 5). During storage, the viability of probiotics was decreased (Fig. 1) due to increase in acidity. During storage, it was absorbed that there existed good viability of probiotic count which may be due to the suitable $\mathrm{pH}$ (3.80 to 4) condition for the growth of probiotics.

Tungrugsasut et al., (2012) reported that the initial count of probiotics in probiotic yoghurt in 3 per cent was $126 \times 10^{8} \mathrm{cfu} / \mathrm{ml}$ and that of 4 per cent was $129 \times 10^{8} \mathrm{cfu} / \mathrm{ml}$. The counts of probiotic in the two formulae were decreased gradually after storage. After 30 days of storage, the counts of probiotic in 3 per cent and 4 per cent probiotic yogurt were $61 \times 10^{8} \mathrm{cfu} \mathrm{m}^{-1}$ and $64 \times 10^{8} \mathrm{cfu} \mathrm{ml}^{-1}$ respectively.

\section{Yeast and mould count}

The yeast and mould growth in probiotic enriched shrikhand was analysed at the regular intervals viz., $10^{\text {th }}, 20^{\text {th }}$ and $30^{\text {th }}$ days of storage. Initially there was no yeast and mould growth (Table 3) in probiotic enriched shrikhand in the dilution factors $10^{1}$ to $10^{4}$. During the storage of probiotic enriched shrikhand also, there was no growth in the samples $\left(\mathrm{T}_{\mathrm{s}}\right.$ and $\left.\mathrm{T}_{\mathrm{m}}\right)$. Lakshmi et al., (2013) also observed no yeast and mold count upto $7^{\text {th }}$ day of storage of shrikhand, and after which a gradual increase of yeast and mold were observed up to $9 \mathrm{cfu} / \mathrm{g}$ counts on the $25 \mathrm{th}$ 
day of storage. Coliform count was found to be nil thorough out the storage period.

From the study, it could be inferred that the probiotic shrikhand using L. acidophilus was highly acceptable than shrikhand prepared using mixed probiotic strains (L. acidophilus and $L$. rhamnosus) during storage. The reason may be because the mixed probiotic strains produced more acidity than the single strain. Storage studies revealed that the probiotic shrikhand had good storage stability during the period of study (30 days) at refrigeration temperature $\left(4^{\circ} \mathrm{C}\right)$. The probiotic shrikhand could thus serve as good carrier of probiotics to improve gut health and may also be recommended for lactose intolerant individuals.

\section{References}

Amerine, M. A., Pangborn. R. M. and Roseller, E. B. 1965. Principles of sensory evaluation of food. Academic Press. New York.131.

Aneja, R. P. Mathur, B. N. Chandan. A.K. and Barnejee, A. K. 2002. Technology of Indian Dairy Products: Handbook on process technology modernization for professionals entrepreneurs and scientists. A Dairy India Publication Delhi, India.

AOAC, 1995. Official methods of analysis. $14^{\text {th }} \mathrm{Edn}$. The Association of official Agricultural Chemists. Washington, D. C.

Desai, H. K. and Gupta, S. K. 1986. Sensory evaluation of shrikhand. Dairy Guide, 15 (11): 14

Istavankiss. 1984. Testing methods in food microbiology. Elsevier. 395-397.

Kumar. S., Z.F. Bhat. and Pavan. K. 2011. Effect of apple pulp and Celosia argentea on the quality characteristics of shrikhand. American Journal of Food Technology. 6 (9): 817-826.

Lakshmi. R., B. Ranganna and K. B. Suresha. 2013. Development of value rich jamun fruit shrikhand. Mysore Journal of Agricultural Sciences. 47(2): 307-313.

Manjula K., Viswanath C. and Suneetha C. 2012. Physico-chemical, sensory and microbial quality of yoghurt fortified with sapota pulp. International Journal of Material Sciences and Chemistry. 1(1): 004-006.

Nigam. N., Rashmi. S. and P.K. Upadhayay. 2009. Incorporation of Chakka by Papaya Pulp in the Manufacture of Shrikhand. Journal of Dairying Foods. 28(2): 115118.

Raghuwanshi. R.T., N.A. Mankar, R.A. Deshmukh. and S.B. Deshmukh. 2011. Effect of source and storage interval on reducing, non-Reducing sugar content of shrikhand. Journal of Dairying Foods. 30 (2): 105- 109.

Tungrugsasut. W., Wiwat. C., Srisukh. V., Thoophaew. K. and Tippawat. P. 2012.Probiotic frozen yogurt. Mahidol University Journal of Pharmaceutical Sciences 2012. 39 (3-4): 24-31.

World Health Organisation. 2001. Evaluation of health and nutritional properties of powder milk and live lactic acid bacteria. Food and Agriculture Organization of the United Nations and World Health Organization Expert Consultation Report. Yeganehzad. S., Mostafa. M.T. and Fakhri. S. 2007. Studying microbial, physiochemical and sensory properties of directly concentrated probiotic yoghurt. African Journal of Agricultural Research. 2 (8): 366-369,

\section{How to cite this article:}

Sivasankari, R., G. Hemalatha, S. Kanchana and Umamaheswari, T. 2017. Standardization and Evaluation of Probiotic Shrikhand. Int.J.Curr.Microbiol.App.Sci. 6(11): 41-47. doi: https://doi.org/10.20546/ijcmas.2017.611.005 